\title{
Pemodelan Background Traffic pada Jaringan Berkapasitas Terbatas
}

\author{
Jay Idoan Sihotang \\ Fakultas Teknologi Informasi, Universitas Advent Indonesia \\ e-mail: jayidoans@unai.edu
}

\begin{abstract}
Abstrak
Perkembangan teknologi yang begitu cepat mempengaruhi berbagai aspek dalam kehidupan. Dan hal tersebut yang menjadikan penggunaan teknologi Internet menjadi bagian dalam menjalankan kegiatan sehari-hari. Namun kebutuhan atas jaringan Internet yang memadai terhambat dengan terbatasnya kapasitas bandwidth dalam jaringan. Pengukuran yang dilakukan pada jaringan pengujian berkapasitas terbatas bertujuan untuk mengetahui karakteristik dari jaringan pengujian dan tingkat laju traffic dalam jaringan tersebut. Pada jaringan pengujian didapati rata-rata kapasitas bandwidth sebesar 3,61 Mbps, dan rata-rata tingkat laju traffic sebesar 1,428 Mbps. Tingkat laju traffic yang terjadi dalam jaringan pengujian bernilai 1/3 dari kapasitas bandwidth tertinggi pada jaringan pengujian yaitu 4,76 Mbps. Dengan karakteristik penyampaian paket yang bersifat continuous sebesar $70 \%$, dan paket yang bersifat bulk sebesar $30 \%$. Melalui hasil karakteristik penyampaian paket tersebut, pemodelan background traffic yang dibangun menggambarkan transmisi paket yang bersifat bulk akan ditransmisikan setelah 7 paket yang bersifat continuous terkirim. Pemodelan background traffic ini dapat menjadi acuan dalam melakukan simulasi penyampaian konten dalam aplikasi simulasi jaringan yang dibangun menyerupai karakteristik jaringan pengujian.
\end{abstract}

Kata-kata Kunci: Pemodelan Background Traffic, Fluid Model, Jaringan Berkapasitas Terbatas, DSL

\section{The Background Traffic Modeling in Limited Capacity Network}

\begin{abstract}
Rapid technological developments influence various aspects of life. And that makes the use of Internet technology as a part of carrying out daily activities. But the need for adequate Internet networks is hampered by limited bandwidth capacity in the network. Measurements made on limited capacity testing networks aim to determine the characteristics of the testing network and the rate of traffic in the network. In the testing network, the average bandwidth capacity was $3.61 \mathrm{Mbps}$, and the average rate of traffic was 1,428 Mbps. The rate of traffic that occurs in the testing network is worth $1 / 3$ of the highest bandwidth capacity on the testing network which is 4,76 Mbps. With the characteristics of continuous packet delivery of $70 \%$, and bulk packet delivery by $30 \%$. Through the results of the characteristics of the package delivery, the background traffic model that is constructed describing the transmission of bulk packets will be transmitted after 7 continuous packets sent. Background traffic modeling can be a reference in conducting content delivery simulations in network simulations application that resemble the characteristics of testing network.
\end{abstract}

Keywords: Background Traffic Modeling, Fluid Model, Limited Capacity Network, DSL 


\section{Pendahuluan}

Perkembangan Teknologi Informasi bergerak dengan sangat cepat dan mempengaruhi berbagai aspek dalam kehidupan manusia guna menjadi lebih baik, dan sudah menjadi fakta bahwa teknologi Internet sudah menjadi kebutuhan penting dalam menjalankan kegiatan sehari-hari. Kebanyakan dari pengguna mengakses Internet untuk berbagi konten Multimedia mulai dari kebutuhan personal, bisnis, hingga memungkinkan adanya pembelajaran melalui kelas virtual [1]. Di Indonesia pada awal tahun 2015 memiliki total pengguna Internet sebanyak 72.7 juta pengguna [2]. Namun sangat disayangkan jumlah pengguna tidak sebanding dengan kecepatan rata-rata koneksi Internet di Indonesia dengan nilai 1,9 Mbps yang menempatkan Indonesia di posisi ke-122 dari 198 Negara [3]. Luas geografi Indonesia menjadi salah satu penyebab kurang meratanya pengembangan jaringan internet, dan sebagian besar pengguna di daerah hanya dapat menghubungkan diri mereka dengan internet melalui layanan DSL (Digital Subscriber Line) yang memiliki kapasitas bandwidth. Dengan karakteristik layanan DSL memiliki bandwidth downstream yang tinggi, namun bandwidth dari kapasitas upstream bernilai rendah. Di antara beberapa traffic yang terjadi dalam satu jaringan, terdapat background traffic yang memiliki pengaruh terhadap kualitas penyampaian multimedia di jaringan, khususnya jaringan nirkabel IEEE 802.11B [4]. Dan di jaringan ADSL2+ (Asymmetric Digital Subscriber Line), background traffic memiliki pengaruh terhadap panjang delay bersamaan dengan meningkatnya jitter [5]. Untuk melihat dampak dan karakteristik lebih lanjut dari background traffic dalam jaringan, maka penelitian ini melakukan observasi dan pemodelan background traffic dalam jaringan pengujian yang memiliki kapasitas bandwidth terbatas.

\section{Metode Penelitian}

Metodologi yang digunakan dalam penelitian ini dimulai dengan melakukan pengukuran jaringan di lapangan guna mengetahui kondisi aktual dari performa jaringan di lapangan, serta melakukan pengukuran terhadap laju traffic di jaringan. Pemodelan background traffic mengacu kepada kondisi aktual jaringan di lapangan. Jaringan berkapasitas terbatas yang diukur berada di Sukabumi.

\section{Perangkat Lunak Pendukung Penelitian}

Pengukuran terhadap kondisi jaringan dalam penelitian ini membutuhkan beberapa dukungan perangkat lunak/aplikasi. Beberapa aplikasi tersebut digunakan dalam melakukan pengukuran performansi dan kondisi dalam jaringan di lapangan, yang nantinya akan digunakan sebagai acuan dalam melakukan pemodelan background traffic dalam jaringan.

1. JPerf

Jperf merupakan pengembangan dari aplikasi iperf yang digunakan untuk mengetahui kinerja suatu jaringan dengan melakukan pengukuran bandwidth, end-to-end delay, dan tingkat hilangnya datagram yang terkirim [6]. Perbedaan utama dari jperf dan iperf adalah di mana jperf memiliki graphical user interface (GUI) dalam melakukan pengukuran kinerja jaringan, sedangkan iperf tidak memiliki tampilan GUI. Jperf dapat digunakan baik di sisi klien maupun di sisi server. Salah satu fitur yang sederhana dari jperf adalah: Pengguna dapat menampilkan perintah iperf yang dijalankan di belakang aplikasi dengan melakukan klik pada tombol "run iperf". Dalam menjalankan jperf, harus dilakukan konfigurasi terhadap 2 host. Host yang pertama menjalankan jperf sebagai server, dan host yang kedua menjalankan jperf sebagai klien.

2. Wireshark

Wireshark adalah sebuah aplikasi yang mampu melakukan sniffing terhadap paket yang ditransmisikan dalam jaringan, dan memiliki tampilan antar muka (GUI). Wireshark sering kali digunakan sebagai sebuah alat bantu dalam melakukan analisis jaringan. Dengan kemampuan untuk mengenali lebih dari 850 protokol jaringan, aplikasi ini mampu menangkap paket-paket yang ditransmisi dalam jaringan dan menampilkannya secara rinci guna dianalisa. Oleh karena itu wireshark memiliki kemampuan membaca data secara langsung dari koneksi Ethernet, TokenRing, FDDI serial, wireless LAN dengan standar IEEE 802.11, hingga koneksi ATM. Wireshark sering kali digunakan oleh para profesional jaringan, peneliti, hingga pengembang perangkat lunak 
untuk jaringan sebagai alat analisa dalam mengukur beberapa parameter seperti jitter, delay, packet loss, throughput dari bandwidth, dan menangkap protokol yang digunakan pada jaringan tersebut.

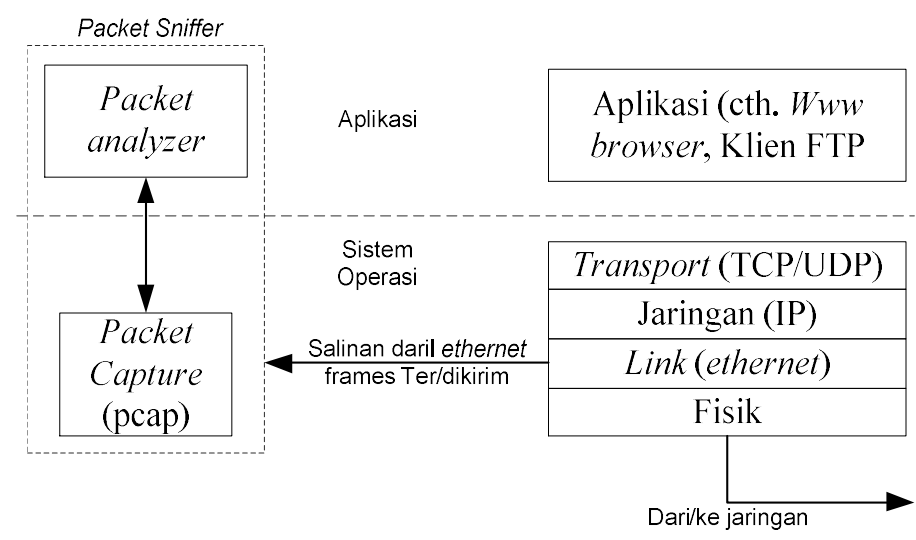

Gambar 1 Struktur Packet Sniffer

Struktur dari packet sniffer terdiri atas dua bagian, yaitu packet analyzer yang bekerja pada lapisan aplikasi, dan packet capture yang berada pada lapisan kerne/atau sistem operasi. Packet sniffer bersifat pasif di mana hanya mengamati dan mengambil paket yang sedang ditransmisi tanpa mengirimkan paket apa pun dalam jaringan.

\section{Parameter Pengukuran Jaringan}

Parameter yang diukur dalam penelitian ini adalah parameter utama mempengaruhi traffic dalam jaringan berkapasitas terbatas. Parameter jaringan yang digunakan adalah bandwidth dan tingkat laju traffic dalam jaringan. Parameter tersebut dipilih sebagai referensi dalam menggambarkan kondisi jaringan di lapangan.

Dalam melakukan pengukuran dalam jaringan, terdapat beberapa teknik yang digunakan untuk mengukur kondisi jaringan di lapangan. Pengukuran terhadap parameter jaringan menggunakan host jaringan di jaringan berkapasitas teratas yang terkoneksi dengan jaringan kampus berkecepatan tinggi melalui VPN kampus. Untuk menangkap variasi dalam pengukuran properti jaringan, pengukuran dilakukan berulang selama 3 hari dengan interval waktu tertentu di jam efektif sekolah. Metode pengukuran parameter jaringan adalah sebagai berikut.

1. Pengukuran Bandwidth

Pengukuran bandwidth dilakukan secara berulang dalam interval waktu tertentu dengan beban traffic yang beragam di tiap waktunya. Pengukuran dilakukan dalam tiga hari dan tiap pengukuran dimulai pada pukul 07.00 WIB dan diakhiri pada pukul 13.00 WIB. Setiap pengulangan dari pengujian dilakukan dalam waktu kurang lebih 10 detik dengan interval jarak antar pengujian kurang lebih 60 menit. Teknik yang digunakan untuk mengetahui kapasitas bandwidth adalah dengan membanjiri kanal bandwidth dengan paket yang dikirim dari host pengirim ke host penerima yang bertujuan untuk mengetahui kapasitas kanal. Kapasitas bandwidth yang diperoleh mungkin lebih kecil atau lebih besar dari asumsi pengalokasian bandwidth. Misalnya, informasi kapasitas bandwidth dari penyedia layanan saat berlangganan.

2. Pengukuran Tingkat Laju Traffic

Pengukuran tingkat laju traffic dilakukan dengan mengawasi dan melakukan observasi terhadap tiap paket yang terkirim/diterima dalam tiap host di jaringan. Observasi tercapai dengan melakukan koneksi terhadap SPAN yang memiliki fitur port mirroring di mana memungkinkan host 
pengawas mengamati tiap paket yang melalui jaringan. Pengukuran berlangsung selama tiga hari, dan dimulai beberapa menit setelah dilakukan pengukuran bandwidth. Observasi jaringan dilakukan selama 20 menit dalam tiap iterasi pengukurannya dengan jeda antar pengukuran kurang lebih 60 menit.

Setelah melakukan pengukuran terhadap jaringan, dilakukan investigasi terhadap kedua parameter pengukuran jaringan yaitu bandwidth dan tingkat laju traffic. Investigasi ini bertujuan untuk menyajikan data yang akurat yang menggambarkan kondisi aktual dari jaringan di lapangan. Langkah investigasi terhadap parameter pengukuran jaringan adalah sebagai berikut.

\section{Bandwidth}

Dilakukan investigasi terhadap hasil pengukuran bandwidth, terutama terhadap data yang dihasilkan selama pengukuran bandwidth dari host pengirim ke host penerima. Alokasi bandwidth diperoleh dari hasil membanjiri kanal broadband. Hasil pengujian tiap iterasi disajikan dalam bentuk tabel dan grafis guna memudahkan proses investigasi kapasitas bandwidth di lapangan. Khususnya kapasitas bandwidth dalam jaringan berkapasitas terbatas.

\section{Tingkat Laju Traffic}

Investigasi terhadap tingkat laju traffic dilakukan dengan mengumpulkan data yang diperoleh dari pengukuran tingkat laju traffic selama tiga hari pengukuran. Data yang berupa rata-rata tingkat laju traffic dalam tiap iterasi disajikan dalam bentuk tabel bersamaan dengan rata-rata jumlah paket per detik dan tingkat laju traffic dalam bytesper detik. Info grafis mengenai fluktuasi tingkat laju traffic disertakan guna mempermudah proses investigasi.

\section{Pemodelan Background Traffic}

Pemodelan background traffic berguna untuk menggambarkan arus traffic yang sesuai dengan hasil penelitian di lapangan. Model ini berkaitan erat dengan nilai tingkat laju traffic yang berada pada bagian sebelumnya. Di mana nilai tingkatan laju traffic menjadi acuan dalam melakukan pemodelan background traffic dalam suatu jaringan tertentu, dan melihat pengaruhnya terhadap penyampaian trafficlainnya dalam jaringan [7]. Pemodelan ini dimulai dengan melakukan investigasi atas hasil penelitian lapangan di jaringan pengujian, kemudian dilakukan pemodelan akan distribusi maupun transmisi paket dalam interval waktu tertentu. Pemodelan dari background traffic haruslah bersifat responsif terhadap kondisi aktual dari jaringan di lapangan [8].

Terdapat beberapa model dari pembentukan traffic dalam jaringan yang dibagi dalam tiga model yaitu model temporal, model fluid, dan model spatiotemporal [9]. Penelitian ini akan menggunakan model fluid yang memodelkan traffic dalam jaringan sebagai arus cairan yang bersifat kontinu [7]. Model fluid dapat digambarkan sebagai serial paket yang melaju dari sumber yang sama menuju tujuan yang sama secara konstan dengan tingkat fluid yang linear dalam jaringan virtual. Pemodelan fluid yang terhitung berdasarkan event menggambarkan alur TCP dengan menggunakan fungsi individual untuk tingkatan yang konstan dan menggunakan event dalam simulasi untuk menyajikan perubahan dari tingkat alur paket tersebut sementara performansi dari alur tersebut ditentukan oleh kondisi dalam jaringan [10]. Model fluid dapat mengurangi kompleksitas dari perhitungan dalam melakukan simulasi sebuah jaringan dengan tingkat alur yang konstan dalam periode waktu yang signifikan.

Sifat dari background traffic terbagi dua dari jenis penyampaiannya yaitu continuous dan bulk [11]. Continuous berarti bahwa transmisi paket yang dilakukan secara terus menerus dalam satu interval waktu dengan besar paket yang relatif konstan. Sedangkan paket yang bersifat bulk hanya ditransmisikan dalam periode tertentu dengan ukuran yang relatif lebih besar daripada paket yang ditransmisikan secara continuous. Kebanyakan traffic yang bersifat continuous menggunakan protokol HTTP/TCP, sedangkan traffic yang bersifat bulkmenggunakan protokol FTP/UDP dalam melakukan transmisi pertukaran data yang relatif besar [12].

Pengamatan akan hasil penelitian lapangan terutama pada nilai tingkatan laju traffic dilakukan dengan melihat nilai rata-rata dari tingkat laju traffic. Nilai tingkatan laju traffic tersebut akan dihitung berdasarkan 
pendistribusian besar paket ke dalam dua sifat dari penyampaian paket tersebut. Hasil dari pengamatan disajikan dalam suatu model ekspresi matematis yang menggambarkan distribusi background traffic yang terjadi dalam jaringan di lapangan.

\section{Pengukuran Jaringan Lapangan}

Jaringan pengujian yang digunakan dalam penelitian ini berlokasi di Sukabumi, Jawa Barat, Indonesia yang berjarak sekitar 95 kilometer dari server di kampus. Jaringan pengujian terhubung dengan server menggunakan koneksi DSL broadband dari salah satu penyedia layanan internet di Indonesia. Host client terhubung dengan server yang berada di kampus dengan menggunakan kanal VPN. Skema topologi jaringan pengujian dapat dilihat pada Gambar 2 berikut ini.

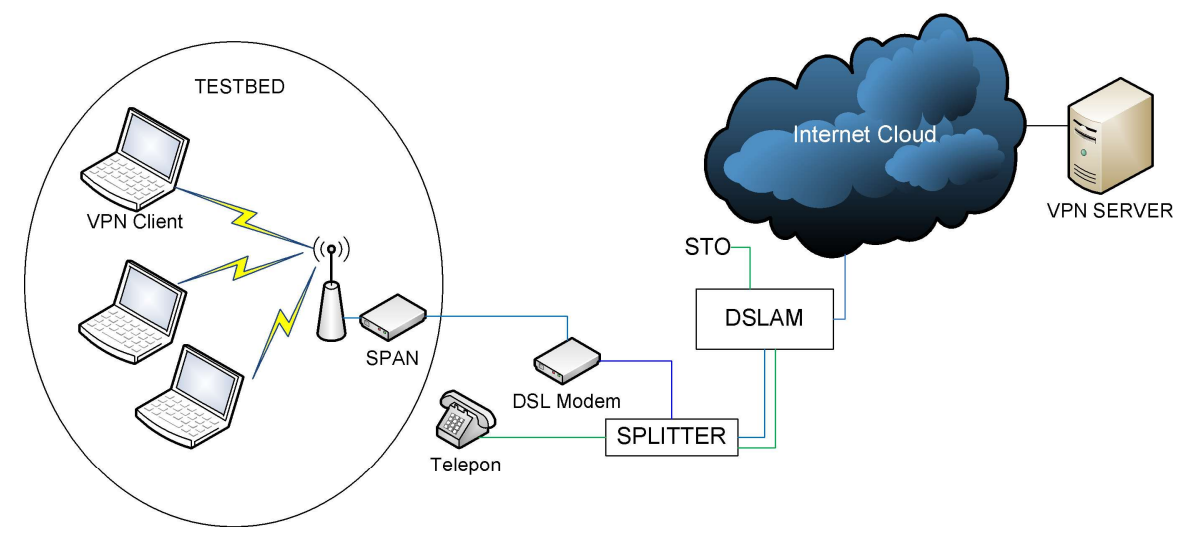

Gambar 2 Topologi Jaringan Pengujian

Pengukuran ini menggunakan beberapa perangkat. Pertama, 1 buah Laptop yang dijadikan host pengukuran di sisi client, 1 buah Desktop yang berfungsi sebagai server, jaringan DSL broadband sebagai objek yang diteliti, 1 buah modem ADSL, dan 1 buah router (SPAN) yang memiliki fitur port mirroring dan port forwarding berbasis RouterOS. Skenario pengukuran yang dilakukan mengacu kepada metode penelitian pada bagian sebelumnya. Adapun skenario dan hasil dari pengukuran jaringan pengujian adalah sebagai berikut.

1. Kapasitas Bandwidth

Kapasitas bandwidth dihitung dengan membanjiri kanal jaringan dengan menggunakan aplikasi jperf. Pengujian dilakukan selama 3 hari pada jam efektif kegiatan belajar di sekolah. Dilakukan sebanyak 7 kali iterasi per hari pengujian.

Hasil pengukuran lapangan terhadap kapasitas bandwidth di jaringan pengujian yang berlokasi di Sukabumi menunjukkan fluktuasi. Fluktuasi kapasitas bandwidth dalam tiap iterasi pengukuran berkisar dari 1.70 Mbps hingga kapasitas bandwidth tertinggi yaitu 4.76 Mbps. Detail dari masing-masing iterasi pengukuran kapasitas bandwidth tersaji dalam Tabel 1 berikut.

Tabel 1. Kapasitas Bandwidth (Mbps)

\begin{tabular}{|c|c|c|c|}
\hline \multicolumn{4}{|c|}{ Hari ke-1 } \\
\hline Iterasi & Durasi (detik) & Transfer Data (MB) & Kapasitas Bandwidth (Mbps) \\
\hline 1 & 10.5 & 5.63 & 4.49 \\
\hline 2 & 11.1 & 3.25 & 2.46 \\
\hline 3 & 10.3 & 4.0 & 3.25 \\
\hline 4 & 10.3 & 2.13 & 1.73 \\
\hline 5 & 11.5 & 2.25 & 1.65 \\
\hline 6 & 10.2 & 5.50 & 4.52 \\
\hline 7 & 11.7 & 2.25 & 1.70 \\
\hline
\end{tabular}




\begin{tabular}{|c|c|c|c|}
\hline \multicolumn{5}{|c|}{ Hari ke-2 } \\
\hline Iterasi & Durasi (detik) & Transfer Data (MB) & Kapasitas Bandwidth (Mbps) \\
\hline 1 & 10.2 & 4.63 & 3.80 \\
\hline 2 & 11 & 5.50 & 4.19 \\
\hline 3 & 10.4 & 5.88 & 4.76 \\
\hline 4 & 10.5 & 4.00 & 3.19 \\
\hline 5 & 10.2 & 5.75 & 4.75 \\
\hline 6 & 10.4 & 5.88 & 4.75 \\
\hline 7 & 10.3 & 5.50 & 4.46 \\
\hline \multicolumn{5}{|c|}{ Hari ke-3 } \\
\hline Iterasi & Durasi (detik) & Transfer Data (MB) & Kapasitas Bandwidth (Mbps) \\
\hline 1 & 10.7 & 3.25 & 2.54 \\
\hline 2 & 10.2 & 5.13 & 4.21 \\
\hline 3 & 11.2 & 2.38 & 4.78 \\
\hline 4 & 10.9 & 5.75 & 4.44 \\
\hline 5 & 10.2 & 5.13 & 4.20 \\
\hline 6 & 10.4 & 5.38 & 4.34 \\
\hline 7 & 10.4 & 5.63 & 4.53 \\
\hline
\end{tabular}

Berdasarkan dari data di Tabel 1 di atas, terjadi fluktuasi dalam tiap iterasi pengukuran. Dengan membanjiri kanal bandwidth selama 10 detik dengan 7 iterasi per hari dalam 3 hari penelitian, dapat terlihat bahwa rentang kapasitas bandwidth cukup bervariasi. Pengukuran jaringan di jaringan pengujian Sukabumi menghasilkan nilai rata-rata kapasitas bandwidth sebesar $3.61 \mathrm{Mbps}$, dengan nilai kapasitas bandwidth terendah sebesar $1.70 \mathrm{Mbps}$, dan nilai kapasitas bandwidth tertinggi sebesar 4.76 Mbps. Info grafis mengenai fluktuasi kapasitas bandwidth selama pengukuran dipresentasikan melalui Gambar 3 di bawah ini.

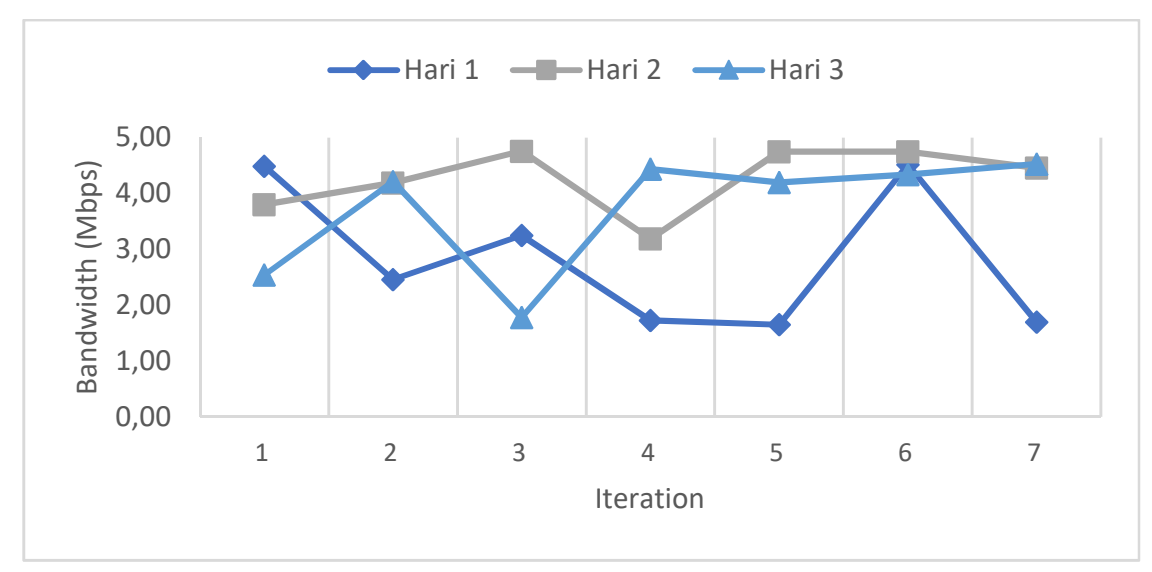

Gambar 3. Fluktuasi Kapasitas Bandwidth di Jaringan

2. Tingkat Laju Traffic

Tingkat laju traffic diukur melalui observasi jaringan menggunakan aplikasi wireshark. Untuk dapat melakukan observasi terhadap lalu lintas jaringan, dibutuhkan konfigurasi port mirroring melalui aplikasi Winbox yang berjalan di atas RouterOS atau lebih dikenal dengan teknik SPAN. Pengujian dilakukan selama 3 hari pada jam efektif kegiatan belajar mengajar di sekolah.

Hasil observasi dan pengukuran terhadap tingkat laju traffic di jaringan pengujian yang berlokasi di Sukabumi, menunjukkan tingkatan laju traffic yang komprehensif di tiap iterasi pengukurannya. Observasi yang dilakukan selama tiga hari dengan variasi perangkat yang terkoneksi dengan jaringan pengujian menghasilkan fluktuasi data yang dapat dilihat di Tabel 2 . 
Tabel 2. Rata-rata Tingkat Laju Traffic (Mbps)

\begin{tabular}{|c|c|c|c|}
\hline \multirow{2}{*}{ Iterasi } & \multicolumn{3}{|c|}{ Tingkat Laju Traffic } \\
\cline { 2 - 4 } & Hari 1 & Hari 2 & Hari 3 \\
\hline 1 & 1.250 & 1.510 & 1.363 \\
\hline 2 & 1.245 & 1.266 & 0.591 \\
\hline 3 & 1.071 & 1.305 & 0.711 \\
\hline 4 & 3.905 & 1.256 & 0.941 \\
\hline 5 & 0.551 & 1.906 & 0.700 \\
\hline 6 & 0.980 & 1.966 & 0.760 \\
\hline 7 & 1.337 & 3.123 & 2.248 \\
\hline
\end{tabular}

Fluktuasi data yang terjadi dalam pengamatan disebabkan oleh jumlah koneksi yang tersambung dengan AP serta penggunaan aplikasi internet yang mempengaruhi tingkat laju traffic. Rata-rata tingkat laju traffic terendah terjadi pada hari pertama pengamatan pada iterasi ke-5 yaitu sebesar 0,551 Mbps. Yang menarik adalah rata-rata tingkat laju traffic tertinggi terjadi pada hari yang sama dengan nilai 3,905 Mbps yang terjadi pada iterasi ke-4. Hari ke-2 dari pengamatan menunjukkan tingkat laju traffic yang lebih stabil dibandingkan dengan hari pertama dan hari ketiga. Rata-rata tingkat laju traffic yang terjadi selama pengujian adalah sebesar 1,428 Mbps. Tingkat laju traffic jika dibandingkan dengan kapasitas bandwidth bernilai $1 / 3$ dari kapasitas bandwidth pada jaringan pengujian. Gambaran mengenai fluktuasi tingkat laju traffic disajikan melalui Gambar 4 di bawah ini.

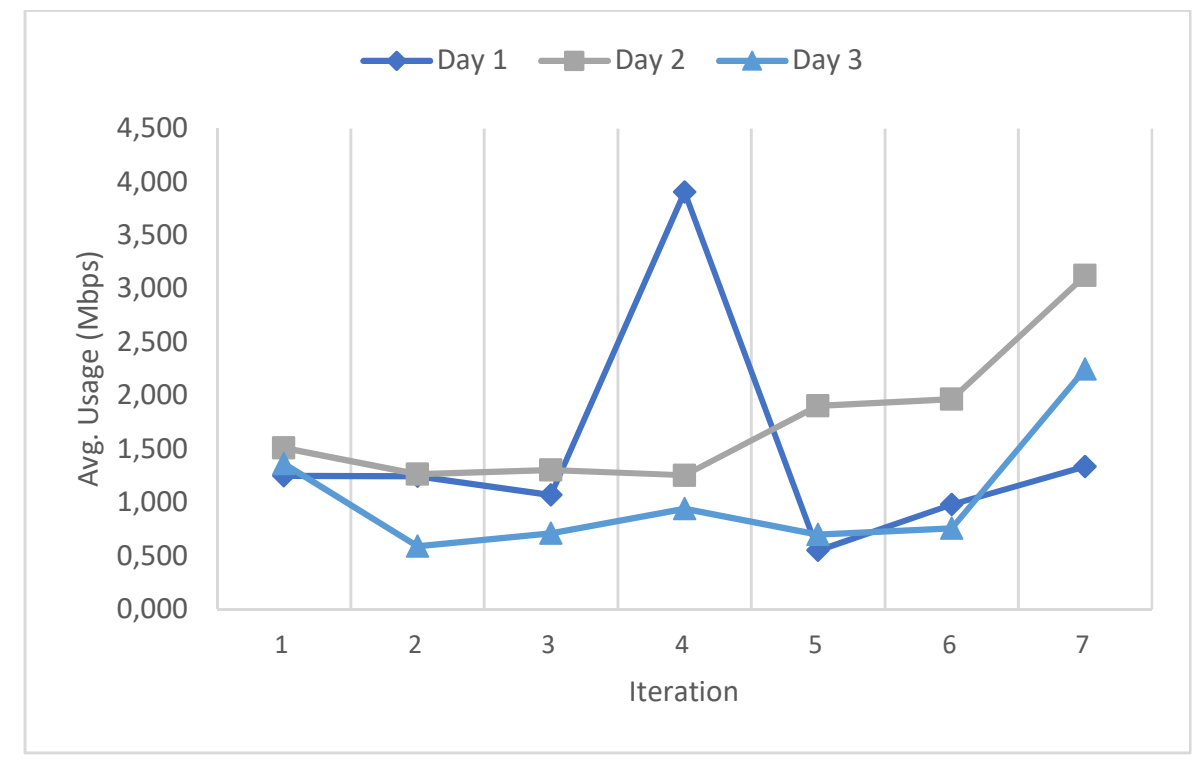

Gambar 4. Fluktuasi Tingkat Laju Traffic

\section{Pemodelan Background Traffic}

Pemodelan background traffic mengacu kepada hasil penelitian lapangan yang dilakukan di jaringan pengujian Sukabumi selama tiga hari penelitian. Khususnya kepada besar nilai tingkat laju traffic yang menggambarkan besar laju paket dalam jaringan pada interval waktu tertentu. Rata-rata dari besar tingkat laju traffic dalam jaringan adalah 1.428 Mbps, yang bernilai kurang lebih $30 \%$ dari kapasitas bandwidth tertinggi yaitu 4.76 Mbps. Untuk dapat melakukan pemodelan terhadap background traffic yang terjadi di dalam jaringan, diperlukan karakterisasi dari penyampaian paket dalam jaringan. 
Tabel 3. Karakterisasi Penyampaian Paket (Jumlah Paket)

\begin{tabular}{|c|c|c|c|c|c|c|}
\hline \multirow{2}{*}{$n$} & \multicolumn{2}{|c|}{ Hari ke-1 } & \multicolumn{2}{c|}{ Hari ke-2 } & \multicolumn{2}{c|}{ Hari ke-3 } \\
\cline { 2 - 7 } & Cont. & Bulk & Cont. & Bulk & Cont. & Bulk \\
\hline 1 & 187000 & 105190 & 174679 & 116452 & 314417 & 42876 \\
\hline 2 & 114921 & 140459 & 191663 & 57245 & 184412 & 25984 \\
\hline 3 & 175140 & 68380 & 236308 & 51872 & 161973 & 59302 \\
\hline 4 & 278508 & 435524 & 179910 & 88612 & 190565 & 83414 \\
\hline 5 & 130465 & 23023 & 351879 & 96375 & 189051 & 36010 \\
\hline 6 & 263752 & 29306 & 349329 & 87334 & 185792 & 40783 \\
\hline 7 & 199825 & 133218 & 280633 & 292086 & 379979 & 94994 \\
\hline
\end{tabular}

Tabel 3 menunjukkan karakterisasi dari penyampaian paket dalam jaringan saat melakukan pengukuran lapangan, bersamaan dengan pengukuran tingkat laju traffic. Dengan total 6828640 paket ditransmisikan selama observasi, paket yang memiliki karakteristik penyampaian secara kontinu sebesar 4720201 paket. Transmisi paket yang bersifat kontinu adalah sebesar $70 \%$ dari total paket yang ditransmisikan selama observasi. Sedangkan persentase transmisi paket yang bersifat bulk berjumlah 30\% dari total transmisi. Hal ini dikarenakan selama 21 iterasi pengukuran dan 3 hari observasi menunjukkan bahwa kebanyakan transmisi paket dalam penelitian lapangan digunakan untuk mengakses video streaming, media sosial, aplikasi permainan online, dan aplikasi chatting mendominasi observasi lapangan. Untuk menentukan besaran nilai dari transmisi paket yang bersifat continuous dan bulk dapat melalui persamaan matematis sebagai berikut.

$$
\frac{T_{r P}}{100} \times B w_{\text {Max }}=\left(\frac{n_{\text {Cont }}}{100} B G c\right)+\left(\frac{n_{\text {Bulk }}}{100} B G b\right)
$$

Melalui persamaan di atas dapat dihitung besaran dari nilai untuk masing-masing background traffic yang ditransmisikan secara continuous (BGC) dan bulk (BGB). Dengan parameter nilai persentase transmisi continuous ( $\mathrm{n}_{\text {cont }}$ ) dan bulk ( $\mathrm{n}_{\text {Bulk }}$ ) yang didapatkan dari penelitian lapangan. Khususnya persentase besaran akses jaringan berdasarkan kedua sifat transmisi paket tersebut. $T_{\text {rp }}$ adalah besaran nilai persentase traffic yang ingin digenerasikan yang dibandngkan dengan nilai bandwidth tertinggi (BW ${ }_{\text {Max }}$ ) yang diperoleh saat melakukan penelitian lapangan.

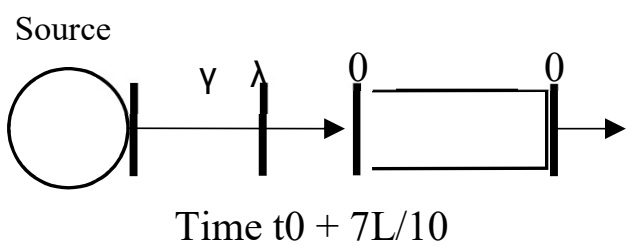

Gambar 5. Pemodelan Background Traffic

Berdasarkan pada karakterisasi penyampaian paket, pemodelan dari background traffic dalam gambar IV.4 menunjukkan bahwa event dilaksanakan saat source pada posisi ON dan traffic dikirimkan dalam rate $\lambda$ yang merepresentasikan traffic bersifat continuous (BGc). Pada posisi t0, tidak ada arus paket yang masuk atau keluar melalui server. Dapat dilihat pada model di atas bahwa terdapat perubahan tingkat laju traffic dari $\lambda$ ke $y$ yang merepresentasikan traffic bersifat bulk(BGb) senilai $7 \mathrm{~L} / 10$ dalam satuan waktu. Hal ini menggambarkan bahwa tipe transmisi paket yang bersifat bulk ditransmisikan dalam besaran waktu tertentu. Dan terjadi sebelum transmisi paket $\lambda$ mencapai server. Pemodelan ini berdasarkan Fluid Model dalam melakukan generasi background traffic [10]. 
Pemodelan background traffic di atas menjelaskan bahwa interval transmisi paket yang bersifat bulk (BGb) akan ditransmisikan setelah 7 paket yang bersifat continuous (BGc) terkirim. Paket yang bersifat bulk dan continuous akan memiliki tingkat penyampaian yang konstan dalam interval waktu yang sudah ditentukan. Sebagai contoh pengaplikasian dalam simulasi jaringan, pengukuran besar dari ukuran paket yang bersifat continuous maupun bersifat bulk diperoleh dengan melakukan kalkulasi terhadap bagian dari masing-masing transmisi dan dikalikan dengan persentase background traffic yang ingin digenerasikan, lalu dibagi dengan 8 untuk mendapatkan nilai transmisi per detik (bps). Untuk mendapatkan ukuran dari masing-masing paket, nilai transmisi paket per detik dikalikan dengan interval penyampaian paket tersebut dalam satuan detik. Dengan pertimbangan bahwa interval transmisi dari background traffic harus diturunkan untuk membatasi ukuran dari paket yang ditransmisikan. Hal ini dilakukan agar ukuran paket yang ditransmisikan berada di bawah ukuran frame ethernet MAC full duplex di jaringan pengujian yang bernilai 1518 byte. Distribusi Background traffic terbagi dalam dua sifat, yaitu continuous (BGc) dan bulk (BGb) dengan perhitungan masing-masing Length (byte) dan Interval (detik) untuk background traffic di jaringan pengujian yang bernilai 30\% dari bandwidth maksimal dapat dilihat pada simulasi distribusi background traffic dalam Tabel 4.

Tabel 4. Simulasi Distribusi Background traffic

\begin{tabular}{|c|c|c|c|c|c|}
\hline \multirow{2}{*}{ BG \% } & Datarate & \multicolumn{2}{|c|}{ BGc } & \multicolumn{2}{c|}{ BGb } \\
\cline { 3 - 6 } & $($ Mbps $)$ & Length & Interval & Length & Interval \\
\hline 30 & 1.428 & 249.9 & 0.002 & 749.7 & 0.014 \\
\hline
\end{tabular}

\section{Kesimpulan}

Dalam melakukan pemodelan background traffic pada jaringan berkapasitas terbatas, dibutuhkan pemilihan jaringan pengujian yang memiliki koneksi DSL atau lebih tepatnya kapasitas bandwidth terbatas. Pengukuran terhadap kapasitas bandwidth menunjukkan karakteristik dari jaringan pengujian. Dan tingkat laju traffic dalam jaringan mendefinisikan kepadatan arus baik foreground traffic ataupun dalam kasus ini background traffic. Dengan melakukan pengukuran terhadap karakteristik penyampaian paket dalam jaringan, didapati bahwa transmisi yang bersifat kontinu sebanyak $70 \%$ dan transmisi paket yang bersifat bulk sebanyak 30\%. Berdasarkan dari hasil pengukuran tersebut, pemodelan background traffic yang dibangun menggambarkan transmisi paket yang bersifat bulk akan ditransmisikan setelah 7 paket yang bersifat continuous terkirim. Pemodelan background traffic ini berguna dalam menggambarkan karakteristik background traffic dalam jaringan, khususnya menjadi acuan dalam melakukan simulasi distribusi background traffic yang menyerupai karakteristik jaringan pengujian.

\section{Referensi}

[1] Y. Bandung, Erwin dan M. T. Hutabarat, "Network Characterization for Delivering Multimedia-based Learning in Rural Areas," dalam International Conference on Advances in Education Technology, 2014.

[2] S. Kemp, "Digital, Social \& Mobile in 2015," We Are Social, Singapore, 2015.

[3] Akamai, "State of The Internet (Q4 2014)," 25 Maret 2015. [Online]. Available: http://www.akamai.com/stateoftheinternet/. [Diakses 28 Maret 2015].

[4] N. Cranley dan M. Davis, "The Effects of Background Traffic on the End-to-End Delay For Video Streaming Applications Over IEEE 802.11B WLAN Networks," dalam IEEE PIMRC, 2006.

[5] G. E. Goncalves, G. G. B. Santos, J. F. Fidalgo, J. Kelner, D. H. F. Sadok dan S. F. d. L. Fernandes, "On The Use Of An ADSL2+ Testbed for Video Quality Assessment," dalam IEEE ICC 2009, 2009.

[6] K. R. Parsons and J. Griffith, "Wireless Lan Proffesionals," February 2011. [Online]. Available: http://wirelesslanprofessionals.com/. [Accessed 03 April 2015]. 
[7] T. Li, "Background Traffic Modeling for Large-Scale Network Simulation," FIU Electronic Theses and Dissertations, Paper 1242, 2014.

[8] K. V. Vishwanath and A. Vahdat, "Evaluating Distributed Systems: Does Background Traffic Matter?," USENIX Annual Technical Conference, pp. 227-240, 2008.

[9] T. LI and J. LIU, "Cluster-Based Spatiotemporal Background Traffic Generation for Network Simulation," ACM Transactions on Modeling and Computer Simulation, vol. 25, 2014.

[10] G. Y. David M Nichol, "Discrete Event Fluid Modeling of Background TCP Traffic," Dartmouth College Departement of Computer Science Technical Report TR2003-454, Hanover, NH, 2003.

[11] M. Tai, S. Ata and I. Oka, "A Classification Method for Bulk/Real-Time Traffic based on Flow Statistics," in Proceedings of Asia-Pacific Network Operations and Management Symposium (APNOMS), Busan, Korea, 2006.

[12] O. Ormond, G. Miro-Muntean and J. Murphy, "Evaluation of an Intelligent Utility-Based Strategy for Dynamic Wireless Network Selection," in 9th IFIP/IEEE International Conference on Management of Multimedia and Mobile Networks and Services, Dublin, Ireland, 2006. 